\title{
後方進入脊椎短縮術を行った骨粗鬆症性椎体骨折例の検討
}

\author{
久留米大学整形外科 \\ 佐 藤 公 昭 - 永田見生 \\ 朴珍 守・神 保幸太郎 \\ 横須賀 公 章
}

\section{Posterior Spinal Shortening with Spinous Process Wiring for \\ Osteoporotic Vertebral Fractures with Neurological Deficit}

\author{
Kimiaki Sato, Kensei Nagata, Jin Soo Park, \\ Kotaro Jimbo, and Kimiaki Yokosuka \\ Department of Orthopaedic Surgery, Kurume University School \\ of Medicine, Kurume, Japan
}

\begin{abstract}
In this study we retrospectively reviewed nine cases in which posterior spinal shortening with spinous process wiring was used to treat an osteoporotic vertebral fracture. The average age at surgery was 76 (64-85) years. T12 was collapsed in two patients, T12 and L1 in three, L1 in two, L2 in one, and L3 in one. All patients complained of neurological deficit. Five were unable to walk, and the other four were unable to walk without a cane. The average follow-up period was 17 months after surgery. Local kyphosis was 26.6 degrees preoperatively, 8.9 degrees postoperatively, and 21.4 degrees at the most recent follow-up examination. There were two cases of postoperative complication : one of intervertebral pseudoarthrosis, and the other deep wound infection. All patients obtained significant relief from neurological deficit ; three could walk without a cane, and the other six with a cane.
\end{abstract}

Key words : osteoporosis (骨粗鬆症), vertebral fracture（椎体骨折）, spinal shortening（脊椎短縮術）

\section{はじめに}

骨粗鬆症性椎体骨折は日常診療でよく遭遇する疾患 であり, 多くは保存療法で治癒する。しかし, 神経障 害が発生した場合には手術療法を考慮する必要がある. 今回, 神経障害を伴った骨粗鬆症性椎体骨折に対して, 棘突起ワイヤリングを用いて後方進入脊椎短縮術を行っ た症例を検討したので報告する。

\section{対象および方法}

対象は 2000 年 6 月以降に手術を行った 9 （男性 1 , 女性 8 ) 例で, 年齢 76 (64-85) 歳, 骨折部位は $\mathrm{T} 12 ： 2$ 例, T12 と L1 の 2 椎体が骨折していたもの
3 例，L1：2 例，L2，L3 が各 1 例であった。術後経 過観察期間は平均 17 か月であった。

手術法は, 後方進入で椎弓切除を行い, 後側方から 椎体後壁に到達した。原則として, 椎体後壁が全体的 に脊椎管に突出する夕イプでは上下の椎間板・椎体終 板を含めて切除した．椎体後壁の突出が上方あるいは 下方のみの夕イプでは 1 椎間のみの操作とし, 切除骨 を椎体間に移植した。用手的に背部を圧迫して後弯を 矯正し, 罹患椎上下の棘突起をワイヤーで締結した. 切除骨に余裕があれば，後側方に骨移植を追加した．

後療法は, 翌日からベッドアップを行い下肢運動訓 練を開始, 疼痛の程度を見ながら 1 週間以内には起立 歩行訓練を開始した。術後の外固定は, 半硬性コルセッ 


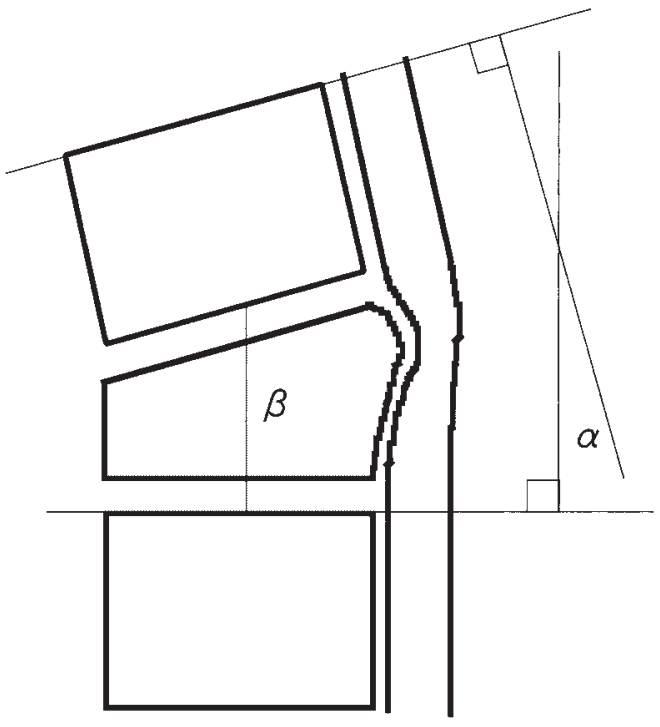

局所後弯角 $(\alpha)$

術 前

術直後

26.6 度

最 終

8.9

矯正損失

21.4

（5度以下：2例、10度以下：4例）

椎間中央高 $(\beta)$

術 前
術直後
最 終
術前—最終

$28.7 \mathrm{~mm}$

27.0

24.1

4.6

図 1 X 線学的検討.

局所後弯角 $(\alpha)$ ：罹患椎体の上下終板のなす角度

椎間中央高 $(\beta)$ ：隣接する上下椎の終板中央間の距離

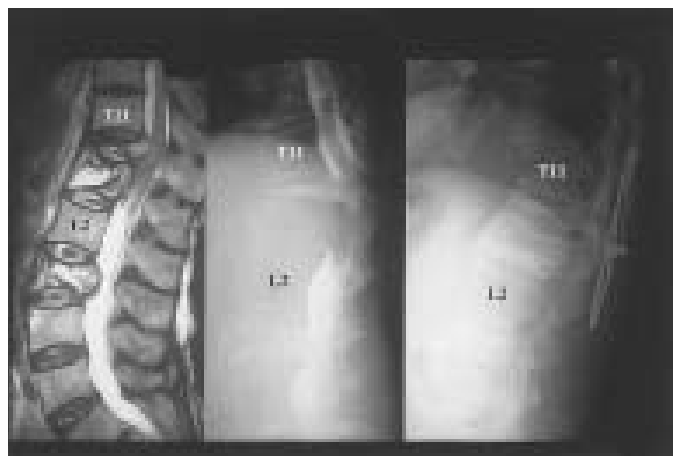

a.

b.

c.

図 264 歳, 女性.
a. 術前 MRI T2 強調像
b. 術前脊髄造影
c. X 線像（術後 1 年 7 只月）

トを 2 〜 か月，その後軟性コルセットを 2 か月間装 着した。
結
果

手術時間は 215（175－290）分，術中出血量は 688 （150－1490）g であった．術前に歩行不能であった 5 例中 3 例は支持歩行が可能となり, 2 例は独歩可能と なった。術前に支持歩行であった 4 例中 1 例は独歩可 能となった。 最終調査時, 症状が進行した例はなかっ たが，ワイヤーの折損を 2 例に認め，うち 1 例は偽関 節となり, 現在経過観察中である. また深部感染を 1 例に認めたが, 術後 3 か月で抜釘を行い鎮静化した.

局所後弯角は術前平均 26.6 度, 術直後 8.9 度, 最 終調査時 21.4 度であり, 矯正損失は 12.6 度であった。 5 度以下の矯正損失は 2 例, 10 度以下は 4 例で, 9 例中 6 例は 10 度以下の矯正損失であった。椎間中央 高は術前 $28.7 \mathrm{~mm}$, 術直後 $27.0 \mathrm{~mm}$, 最終調查時 $24.1 \mathrm{~mm}$ であった。術直後の短縮は $1.7 \mathrm{~mm}$ であった が, 最終調査時には術前と比べ $4.6 \mathrm{~mm}$ 短縮していた (図 1).

症例

64 歳, 女性. 誘因なく腰背部痛が出現, 徐々に下 肢筋力が低下し歩行不能になった。 パーキンソン病を 合併しており，元来歩行障害があった，術前の MRI では T12，L1，L3 と多椎体に圧迫骨折を認め，春䯣 造影では T12，L1レベルで造影柱が欠損していた。 
T11/12 から T12/L1 までを除圧し，T11 と L1 の棘 突起をワイヤーで締結して短縮操作を行った。術後 1 年 7 か月の時点で，支持歩行が可能である（図 2 ）.

\section{考察}

骨粗鬆症性椎体骨折の手術適応は遷延治癒あるいは 偽関節による高度な疼痛がある場合，著しい後弯変形 を認める場合，椎体後壁の脊柱管内突出による神経障 害を認める場合である ${ }^{4)}$.

手術方法として，神経障害を認めず腰背部痛が遷延 した椎体偽関節では椎体内注入療法の適応である ${ }^{6)}$ が, 椎体後壁が春柱管内に突出して神経障害を認める場合 には除圧固定術が必要である。方法として前方法 ${ }^{2)}$,

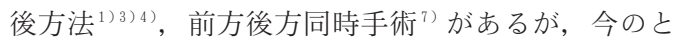
ころ統一された選択基準はない.

手術適応となる症例は，高齢者で何らかの全身合併 症を有す場合が多いため，不要な手術侵襲を避ける必 要がある．脆弱な骨粗鬆椎体を強固な金属材料を用い て固定しても矯正損失は避けられず1)233)7，一定の頻 度で弛みや脱転を生じる。また強固に固定する程，術 後隣接椎体への影響が危惧される。さらに手術操作と は別に，すでに圧迫骨折を認める骨粗鬆症例では他の 椎体に圧迫骨折が一定の頻度で発生することが明らか になっており ${ }^{5)}$ ，この自然経過む十分考慮する必要が ある，後方法で強固な金属材料を用いた場合，背部の 軟部組織が薄い例では内固定材料の突出による皮膚障 害を起こすことがある ${ }^{2)}$ が，本法ではそのような危惧 は不要である。また術後感染に対する対応むワイヤー が浅層にあるため比較的容易である.

本手術法のポイントは，まず十分な除圧操作にある. 脊柱管内に突出した椎体後壁は周囲組織と癒着してい ることが多く, 切除の際ある程度の出血は避けられな
いがこの手技が不十分だと麻痺の改善は望めない，次 いで，十分な後弯矯正が必要である。下位胸椎では後 弯角 0 度，腰椎では軽度前弯位を目標に矯正する。そ して必要十分かつ最小限の内固定を行う。経過ととも に脊椎は短縮するため固定力は術後短期間に限られた あのと考えている。しかし，コルセットによる外固定 を行うことで，比較的早期より後療法む可能であり， むしろ自然な短縮を阻害しない手術法と思われる.

\section{ま と め}

1. 後方進入脊椎短縮術を行った骨粗鬆症性椎体骨折 の 9 例について検討した.

2. 椎体間に骨移植を行い, 隣接上下椎の棘突起をワ イヤーで締結する本法で比較的良好な成績を得るこ とができた。

\section{文献}

1）石川雅之，小野俊明：骨粗鬆症性春椎圧迫骨折に対す る後方進入椎体内 hydroxyapatite block 移植術. 関節 外科, $23: 388-396,2004$.

2）伊東 学ら：骨粗鬆症性椎体圧潰における前方脊柱再 建の長期臨床成績. 日整会誌，78：256-260， 2004.

3）三上靖夫ら：骨粗鬆症性椎体圧潰に対する脊椎後方短 縮術。関節外科, $23: 398-405,2004$.

4）永田見生：骨粗鬆症性脊椎骨折による神経障害に対す る後方進入脊椎短縮術。日整会誌， $78 ： 250-255 ， 2004$.

5）中村利孝：骨粗鬆症に扔ける薬物治療の最新動向。春 椎脊髄， $16 ： 933-938 ， 2003$.

6）武政龍一, 山本博司：Orthopractice 私の治療法. 退 行性骨粗鬆症の圧迫骨折治療. DEBATE 椎体内注入派. Arthritis一運動器疾患と炎症一, 1：188-195, 2003.

7）田中雅人, 中原進之介, 竹内一裕：骨粗鬆症性椎体圧 潰に対する一期的前方・後方手術一triple rod fixation一. 関節外科, $23: 412-418,2004$ 